\section{Current Trends in Russian Higher Education}

\section{Anna Smolentseva}

Anna Smolentseva is on the staff of the Center for Sociological Studies, Moscow State University. Address: 11 Mokhovaya St., Moscow, Russia 103009. Fax: (7-095) 203-6334. E-mail: <anna@opinio.msu.ru>.

$\mathrm{O}$ ver the past several years, Russian higher education has experienced significant change due to the transformation of Russian society and to educational reforms that began in the mid-1980s. The innovation process was aimed at reforming Soviet education and its orientation to the needs of the military-industrial complex, which could not meet the demands of a market environment and global challenges. Significant changes have been introduced in Russian higher education in the following areas:

- in goals - with an orientation toward the needs of the market, society, and individuals;

- in structure-decentralization (in contrast to Soviet centralized planning);

- in the autonomy of higher educational institutionsthe emergence of private higher education, four- and twoyear programs along with the traditional five-year program; and the elimination of a bias toward engineering specialties;

- in financing-diversification of financial sources instead of a reliance solely on state financing; and

- in content-increasing the humanitarian components in the curriculum, and diversifying programs and courses.

At present, Russian higher education includes 914 higher education institutions (universities, institutes, and academies), of which 334 are private. There are 3,347,000 students enrolled in public institutions of higher learning $(2,040,000$ of them full-time), and 251,000 in private postsecondary institutions. The student/faculty ratio at public institutions is 13:4. In comparison, in 1985 there were 502 higher education institutions (all public), with 2,966,000 enrolled students. Such an expansion of the higher education system has happened despite a declining federal budget for education.

\section{The Content of Education}

The problem of implementing a new educational paradigm has been widely discussed recently among educators, sociologists, and psychologists. It is now recognized that methods and ways of teaching must change to achieve qualitative educational and social advancement. Education should emphasize personal development and not only acquiring knowledge and professional training. The student should be considered an active participant in learning, not only a passive "recipient" as is the case now.

Innovations in content include government educational standards, recently developed to ensure unified content in higher education throughout the country.

\section{Higher Education Finance}

Reduced state financing has meant that higher education institutions themselves must engage in fund raising. Two main sources of revenue are renting out facilities and offering fee-based educational services. One of the problems is that there is no longer a tradition of philanthropy and donation in Russia. An adequate taxation policy could bring about a renewal of this tradition. Another possible solution to financial problems is the ongoing integration of different higher education institutions. This process involves many challenges: defining integration principles, determining the status of the respective institutions, and establishing governance procedures and the legal basis for the system. Quite a new issue for Russia is the creation of research universities, which by combining science and commercial production would not only be self-supporting but would also foster economic development.

\section{The Quality of Teaching and Evaluation}

The quality of teaching and evaluation remains a problem for Russian education, given the growing demand for staff and the changing market requirements for education and teaching. Another question of great concern is the aging faculty, which also effects the quality of teaching. In these circumstances, Russian higher education lacks effective evaluation procedures. A recently introduced contract system (for faculty members) has not had the expected effect, being treated only as a formal process.

\section{At present, Russian higher education includes 914 higher education institu- tions (universities, institutes, and acad- emies), of which 334 are private.}

\section{Higher Education and the Labor Market}

The relationship between higher education and the labor market has been radically transformed in recent years. In the Soviet period, the connection was determined by the centralized planning system, which decreed what kind of specialists and in what numbers should be prepared. Jobs were guaranteed for every graduate. Currently, the lack of coordination between higher education and the labor market is exacerbated by the absence of clear state education policies and of a broader strategic plan for Russian development. The new autonomy of higher education institutions allows them to 
make their own decisions on programs. This has resulted in an inappropriate specialty structure-in particular, an excessive quantity of graduates in economics and law.

As for graduates, they have to search for jobs on their own. The competitiveness of graduates in the labor market depends not only on their specialty, the prestige of the institution, excellent grades, but also on their professional experience. This is one of the main reasons why full-time students take jobs and prefer the more practical disciplines. Given the impoverishment of a large part of the population, another reason students engage in part-time work is to earn some money. This is also true of faculty. Part-time work takes a lot of time, which negatively affects the quality of education and teaching. For example, according to sociological surveys, most working students tend to pay less attention to their studies and lose interest, especially if their jobs do not correspond to their future specialties or they believe that after graduating they will not be able to find jobs in their fields.

\section{Higher Education and Society}

Considering the role and the place of higher education in society, it is important to address the issue of access to education and relationships between higher education and society. During much of the Soviet period, government promoted a policy of full access to higher education for all social strata. However, at present there is an increasing trend of declining access to higher education. Most students (up to 60 percent in some estimates) come from high- and middle-income groups, which comprise approximately onethird of the population. There a several causes of declining higher education access: a significant gap between secondary and higher education-some school graduates cannot gain admission to higher educational institutions without additional paid preparation; the high cost of living, which means that provincial youth are unable to leave home or spend their time on study rather than on earning money. The latter issue also leads to the so-called regionalization of education. Thus, currently, Russian higher education has become an obstacle to social mobility and a powerful tool for stratification.

\section{Reforming Higher Education}

Analysis of current trends in Russian higher education shows that the system faces many challenges: filling up gaps in the law, acquiring management and marketing skills, improving the quality of teaching, finding a balance between federal educational requirements and regional needs, and many others. The first stage of educational reform began in 1986, and the second was to follow in 1997. Two reform options have been debated, but neither has been accepted as yet. Although the proposed plans were imperfect, the discussion revealed that Russian society is not yet ready to undertake radical educational reform.

\section{Employment and Working Conditions of Academic Staff in the European Union}

\section{Jürgen Enders}

Jürgen Enders is on the staff of the Center for Research on Higher Education and Work, Gesamthochschule Kassel, Henschelstr. 4, D-3500 Kassel, Germany. E-mail: <enders@hochschulforschung.uni-kassel.de>.

For 20 years, the academic profession has come under increasing scrutiny. A growing body of literature has emerged on the academic profession in comparative perspective, focusing on closely interrelated problems.

First, the academic profession seems to have suffered a more rapid status loss than in the past. In many countries, the professoriate is seen as having lost its high rank in reputation among various professions, relative losses of income are reported, and junior positions are becoming more risky and less well paid. The notion that academics-the members of an expanding profession with growing importance for society-might consider themselves losers has arisen over the last two decades more strikingly than during previous periods.

Second, the resources at institutions of higher education have become more constrained than in the past. In many industrial countries, the allocation for teaching staff has increased, while basic funding for research has declined. Some of the developments might be called "efficiency gains," but overall the feeling of the impoverishment of higher education is widespread.

Third, the academic profession might lose a considerable portion of its academic guild powers. We note a rise in managerial power within higher education as well as increasing regulatory activities as regards the performance of academics.

Fourth, the academic profession is increasingly publicly blamed for not providing the necessary services to society. The critique ranges from a claim that the academic profession is not adequately ensuring quality standards to the widespread accusation that graduates have not acquired the knowledge and skills required and that research is not sufficiently addressing the most pressing problems of our times.

The sense of "crisis" in the academic profession, the changing role of government in higher education, and hopes for the managerial "miracle" have coincided to create a perception of changing environments and a loss of traditional patterns within the academic profession. The current context involves a decline in status-in terms of public reputation and remuneration; deprofessionalization-in terms of loss of control over tasks and working conditions; a loss of trust in self-steering as opposed to accountability 